\title{
Analisis Kredit Pada Pt Bank Pembangunan Daerah Jawa Timur Tbk Cabang Pembantu Ngunut-Tulungagung
}

\author{
Danny Adrianta ${ }^{1}$, Sri Wahyuni Mega Hastuti ${ }^{1}$ \\ ${ }^{1}$ Magister Manajemen Universitas Islam Kadiri \\ Email: wahyunisrihastuti11@gmail.com
}

\begin{abstract}
Abstrak
Analisis kredit merupakan penilaian terhadap suatu permohonan kredit (baik permohonan kredit baru, perpanjangan/pembaharuan, maupun restrukturisasi) layak atau tidak untuk disalurkan kepada Debitur. Ada beberapa prinsip-prinsip penilaian kredit yang sering dilakukan yaitu dengan analisis 5 C's yaitu : Penilaian Watak (Character), Penilaian Kemampuan (Capacity), Penilaian terhadap modal (Capita), Penilaian terhadap agunan (Collatera), dan Penilaian terhadap prospek usaha nasabah debitur (condition of economy).

Dalam penulisan tesis ini Penulis menggunakan metode pendekatan secara yuridis empiris yaitu suatu cara atau prosedur yang digunakan untuk memecahkan masalah dengan terlebih dahulu meneliti data sekunder yang ada kemudian dilanjutkan dengan penelitian data primer dilapangan.

Berdasarkan hasil penelitian di ketahui bahwa Penggunaan 5C's dalam setiap permohonan kredit merupakan hal yang mutlak dan harus dilakukan untuk menentukan keputusan diterima atau ditolaknya suatu kredit. Di PT Pembangunan Daerah Jawa Timur Cabang Pembantu Ngunut Tulungagung penilaian terhadap permohonan Kredit dimulai dengan meneliti proposal dan berkas permohonan kredit dari calon debitur, kemudian dilakukan penyelidikan terhadap berkas pinjaman, selanjutnya dilakukan penilaian kelayakan kredit yang menggunakan analisis 5 C's, Sebelum diputuskannya permohonan kredit diterima atau tidak, maka setelah penilaian kelayakan kredit, kemudian melalui tahap Wawancara pertama, peninjauan ke lokasi, hingga wawancara kedua. Setelah itu baru diputuskan permohonan kredit tersebut diterima atau tidak. Namun dalam pelaksanaanyan dilapangan ada beberapa kendala sehingga penggunaan 5 C's dalam analisis pemberian kredit tidak dapat dilaksanakan secara optimal, hal ini karena kondisi ekonomi, manajemen Bank dan keadaan Politik dari Negara.

Kata Kunci : Kredit, Analisis.
\end{abstract}

\section{A. Latar Belakang Teoritis}

Aktivitas bisnis merupakan fenomena yang sangat komplek karena mencakup berbagai bidang baik, hukum, ekonomi, dan politik. Dalam kehidupan masyarakat, seringkali dapat dilihat bahwa aktivitas manusia dalam dunia bisnis tidak lepas dari peran Bank selaku pemberi layanan perbankan bagi masyarakat.

Dalam pembicaraan sehari-hari, Bank dikenal sebagai lembaga keuangan yang kegiatan utamanya menerima simpanan giro, tabungan dan deposito. Kemudian Bank juga dikenal sebagai tempat untuk meminjam uang (kredit) bagi masyarakat yang membutuhkannya . Di samping itu Bank juga dikenal sebagai tempat untuk menukar uang, memindahkan uang atau menerima segala macam bentuk pembayaran dan setoran seperti pembayaran listrik, telepon, air, pajak, uang kuliah, dan pembayaran lainnya.

Fungsi utama perbankan Indonesia adalah sebagai penghimpun dana dan penyalur dana masyarakat. Dalam menjalankan fungsinya perbankan di Indonesia haruslah berasaskan demokrasi ekonomi dengan menggunakan prinsip kehati-hatian.

Fungsi Perbankan tidak hanya sekedar sebagai wadah penghimpun dan penyalur dana masyarakat atau perantara penabung dan investor, tetapi fungsinya akan diarahkan kepada peningkatan taraf hidup rakyat banyak, agar masyarakat menjadi lebih baik dan lebih sejahtera daripada sebelumnya.

Salah satu produk bank yang sangat banyak dibutuhkan masyarakat adalah kredit. Masyarakat dalam memenuhi kebutuhannya terutama yang berkaitan dengan pengembangan usahanya memerlukan dana tambahan untuk usahanya agar lebih berkembang. Kredit dalam hal ini diatur dalam Pasal 1 angka 11 UU Perbankan adalah persediaan uang atau tagihan yang dapat dipersamakan dengan itu, berdasarkan persetujuan atau kesepakatan pinjam- 
meminjam antara bank dengan pihak lain yang mewajibkan pihak peminjam untuk melunasi utangnya setelah jangka waktu tertentu dengan pemberian bunganya. Pemberian kredit yang diberikan oleh bank kepada nasabah dimaksudkan untuk memperoleh keuntungan, dalam usahanya bank tidak hanya menyalurkan kredit saja tetapi juga berinvestasi pada kegiatan lain seperti penyertaan modal pada sebuah perusahaan dibidang keuangan.

Bank dalam memberikan pinjamannya kepada debitor, tentu dengan melaksanakan prinsip kehati-hatian. Hal ini memang sengaja disyaratkan oleh Pasal 8 angka 1 UU Perbankan di Indonesia, bahwa setiap rupiah dana yang disalurkan oleh bank kepada masyarakat adalah milik masyarakat juga sehingga tentu bank akan mengembalikan kepada nasabah setiap saat beserta bunganya. Dalam hal ini, selain dari prinsip kehati-hatian tersebut, bank juga harus melakukan analisis terhadap calon debitur yang dilakukan berdasarkan aspekaspek yang dikenal dalam dunia perbankan sebagai "The five C's of Credit" yaitu: Character, Capacity, Capital, Condition, dan Collateral. Hasil analisis bank tersebut apabila ternyata menyetujui permohonan pemberian fasilitas kredit, maka pemberian kredit tersebut dituangkan dalam suatu perjanjian tertulis antara bank dan pemohon kredit tersebut yang kemudian diberi nama perjanjian kredit. Perjanjian tersebut dimaksudkan agar pihak calon nasabah debitur dapat memenuhi tuntutan yang berasal dari pihak bank dan mencegah pihak calon nasabah debitur tersebut melakukan hal-hal yang tidak baik, dan perjanjian kredit ini tidak boleh hanya menguntungkan pihak bank saja, melainkan juga perjanjian yang dibuat oleh kedua belah pihak ini tidak boleh merugikan pihak peminjam/nasabah debitur.

Adapun tujuan secara umum yang hendak dicapai dalam penelitian ini adalah untuk mendeskripsikan secara analisa tentang Manajemen Analisis Pemberian Kredit Untuk Mengurangi Risiko Kredit Macet Di PT Bank Pembangunan Daerah Jawa Timur Tbk Cabang Pembantu Ngunut Tulungagung, sedangkan secara khusus tujuan penelitian ini adalah :
1. Untuk mengetahui pelaksanaan analisis pemberian kredit sehingga mengurangi risiko kredit macet

2. Untuk mengetahui hambatanhambatan dalam pelaksanaan analisis pemberian kredit

\section{B. Metode Penelitian \\ Metode Pendekatan}

Metode pendekatan yang digunakan dalam penelitian ini adalah pendekatan secara yuridis empiris, yaitu suatu cara atau prosedur yang digunakan untuk memecahkan masalah dengan terlebih dahulu meneliti data sekunder yang ada kemudian dilanjutkan dengan penelitian terhadap data primer di lapangan. Pendekatan ini bertujuan untuk memahami bahwa hukum itu tidak sematamata sebagai suatu perangkat peraturan perundang-undangan yang bersifat normatif belaka, akan tetapi hukum dipahami sebagai perilaku masyarakat yang menggejala dan mempola dalam kehidupan masyarakat, selalu berinteraksi dan berhubungan dengan aspek kemasyarakatan, seperti aspek ekonomi, sosial dan budaya.

\section{Spesifikasi Penelitian}

Spesifikasi penelitian dari tesis ini merupakan penelitian yang bersifat deskriptif analitis. Maksudnya yaitu bahwa penelitian ini dilakukan untuk memberikan gambaran secara jelas dan rinci, sistematis dan menyeluruh mengenai segala hal yang berhubungan dengan Manajemen Analisis Pemberian Kredit Untuk Mengurangi Risiko Kredit Macet Pada PT Bank Pembangunan Daerah Jawa Timur Cabang Pembantu Ngunut Tulungagung.

\section{Teknik Penelitian} Populasi

Populasi adalah seluruh obyek atau seluruh individu atau seluruh gejala atau kejadian atau seluruh unit yang diteliti. Sedangkan menurut Soerjono Soekanto, populasi adalah sejumlah manusia atau unit yang mempunyai ciri-ciri atau karateristik yang sama. Dalam penelitian ini, populasi yang diteliti adalah pihak yang terkait dengan Pemberian Kredit pada PT Bank Pembangunan Daerah Jawa Timur Tbk Cabang Pembantu Ngunut Tulungagung.

Pertimbangan penulis memilih populasi PT Bank Pembangunan Daerah 
Jawa Timur Tbk Cabang Pembantu Ngunut Tulungagung adalah :

1. Merupakan Bank Umum Swasta yang berpengalaman di dalam memberikan fasilitas kredit pada masyarakat.

2. Mempunyai reputasi baik dalam masyarakat

3. Koorperatif dan terbuka terhadap suatu studi penelitian.

\section{Teknik Pengambilan Sampel}

Dalam penelitian ini pengambilan sample dilakukan dengan menggunakan teknik Non Random Sampling, jenis yang digunakan adalah metode Purposive Sampling, yaitu penarikan sample bertujuan yang dilakukan dengan cara mengambil subyek berdasarkan pada tujuan tertentu. Teknik ini dipakai karena alasan keterbatasan waktu, tenaga dan biaya, sehingga tidak dapat mengambil sample yang besar jumlahnya dan jauh letaknya.

\section{Responden}

Responden dalam penelitian ini adalah pihak-pihak yang berhubungan erat dengan penelitian, dalam hal ini adalah pihakpihak yang terkait dalam Manajemen Analisis Pemberian Kredit Untuk Mengurangi Risiko Terjadinya Kredit Macet di PT Bank Pembangunan Daerah Jawa Timur Tbk Cabang Pembantu Ngunut Tulungagung, yaitu :

1. Pimpinan Cabang PT Bank Jatim Cabang Tulungagung

2. Marketing dari PT Bank Jatim Cabang Tulungagung

3. Appraisal (penilai barang jaminan) dari PT Bank Jatim Cabang Tulungagung

4. Analis Kreditdari PT Bank Jatim

Cabang Tulungagung

Teknik Pengumpulan Data

Dalam pengumpulan data ini, data yang digunakan adalah data primer dan sekunder, yang akan diperoleh melalui studi kepustakaan dan studi lapangan. Berdasarkan pertimbangan tersebut, maka metode pengumpulan data meliputi :

\section{A. Data Sekunder}

Data sekunder dalam penelitian ini melalui literatur-literatur yang berhubungan dengan kajian penelitian berupa Manajemen Analisa Perkreditan.

\section{B. Studi Lapangan/Data Primer}

Dalam penelitian ini, cara utama untuk mengumpulkan data/informasi adalah dengan melakukan wawancara. Wawancara dilakukan dengan cara mengajukan pertanyaan secara langsung kepada responden yang menjadi sampel/informan penelitian dengan teknik yang dipergunakan adalah wawancara tidak berstruktur (non directive interview), wawancara tidak didasarkan pada suatu sistem atau daftar pertanyaan yang telah disusun lebih dahulu.juga wawancara dilakukan dengan tipe terarah (directive interview) yaitu wawancara menggunakan daftar pertanyaan yang sudah dipersiapkan dahulu.

\section{Analisa Data}

Setelah data yang diperlukan terkumpul, maka akan diidentifikasi dan digolongkan sesuai dengan permasalahan. Data yang diperoleh kemudian disusun secara kualitatif, untuk mencapai kejelasan masalah yang akan dibahas.

Dalam menganalisa data penelitian ini, metode yang digunakan adalah metode analisis kualitatif yaitu suatu tata cara penelitian yang menghasilkan data deskriptif analitis, yaitu apa yang dinyatakan responden secara tertulis atau lisan dan juga perilakunya yang nyata, yang diteliti dan dipelajari sebagai sesuatu yang utuh.

\section{Hasil Dan Implikasi Prosedur Umum Perkreditan}

Prosedur kredit mencakup tentang ketentuan, syarat-syarat atau petunjuk tindakan-tindakan yang harus dilakukan sejak diajukan permohonan nasabah sampai dengan lunasnya suatu kredit yang diberikan oleh Bank. Penyajian konteksnya dalam bentuk urutan langkah-langkah yang lazim dalam prosedur perkreditan yang harus ditangani oleh Bank yaitu :

1. Permohonan Kredit

2. Penyidikan Dan Analisis Kredit

3. Keputusan Atas Permohonan Kredit

4. Pencairan Fasilitas Kredit

5. Pelunasan Fasilitas Kredit

\section{Analisis Kredit}

Analisis kredit merupakan penilaian terhadap suatu permohonan kredit (baik permohonan kredit baru, perpanjangan/pembaharuan, maupun 
restrukturisasi) layak atau tidak untuk disalurkan kepada Debitur.

$$
\text { Ada beberapa prinsip-prinsip }
$$

penilaian kredit yang sering dilakukan yaitu dengan analisis 5 C's. Prinsip pemberian kredit dengan analisis dengan 5 C's kredit dapat dijelaskan sebagai berikut (Rachmdi Usman 2001):

1. Penilaian Watak (Character)

Penilaian watak atau kepribadian calon debitur dimaksudkan untuk mengetahui kejujuran dan itikad baik calon debitur untuk melunasi atau mengembalikan pinjamannya, sehingga tidak akan menyulitkan bank dikemudian hari.

2. Penilaian Kemampuan (Capacity)

Bank harus meneliti tentang keahlian calon debitur dalam bidang usahanya dan kemampuan manajerialnya, sehingga Bank yakin bahwa usaha yang akan

dibiayainya dikelola oleh orang-orang yang tepat, sehingga calon debitur dalam jangka waktu tertentu mampu melunasi atau mengembalikan pinjamannya.

3. Penilaian terhadap modal (Capital) Bank harus melakukan analisis terhadap posisi keuangan secara menyeluruh mengenai masa lalu dan yang akan datang, sehingga dapat diketahui kemampuan permodalan calon debitur dalam menunjang pembiayaan proyek atau usaha calon debitur yang bersangkutan.

4. Penilaian terhadap agunan (Collateral) Untuk menanggung pembayaran kredit macet, calon debitur umumnya wajib menyediakan jaminan berupa agunan yang berkualitas tinggi dan mudah dicairkan yang nilainya minimal sebesar jumlah kredit atau pembiayaan yang diberikan kepadanya.

5. Penilaian terhadap prospek usaha nasabah debitur (condition of economy) Bank harus menganalisa keadaan pasar di dalam dan di luar negeri baik masa lalu maupun yang akan datang, sehingga masa depan pemasaran dari hasil proyek atau usaha calon debitur yang dibiayai Bank dapat diketahui.
Bank dalam memberikan kredit, selain menerapkan prinsip 5 C's juga menerapkan apa yang dinamakan $7 \mathrm{P}$, sebagai berikut (Kasmir 2000) :

1. Personality

Menilai nasabah dari segi kepribadiannya atau tingkah lakunya sehari-hari maupun masa lalunya. Mencakup sikap, emosi, tingkah laku dan tindakan

nasabah dalam menghadapi suatu masalah. Personality hampir sama dengan Character dari 5 C's

2. Party

Yaitu mengklasifikasikan nasabah ke dalam klasifikai tertentu atau golongan-golongan tertentu berdasarkan modal, loyalitas serta karakternya.

3. Perpose Mengetahui tujuan nasabah dalam mengambil kredit termasuk jenis kredit yang diinginkan nasabah.

4. Prospect

Untuk menilai usaha nasabah di masa yang akan datang apakah menguntungkan atau tidak, atau dengan kata lain mempunyai prospek atau sebaliknya.

5. Payment

Merupakan ukuran sebagaimana cara nasabah mengembalikan kredit yang telah diambil atau dari sumber mana saja dana untuk pengembalian kredit yang diperolehnya.

6. Profitability

Untuk menganalisa bagaimana kemampuan nasabah dalam mencari laba.

7. Protection

Tujuannya adalah bagaimana menjaga kredit yang dikucurkan oleh Bank namun melalui suatu perlindungan. Perlindungan dapat berupa jaminan barang atau orang atau jaminan asuransi.

\section{Hambatan-hambatan Dalam Analisis Pemberian Kredit.}

Pada dasarnya analisis $5 \mathrm{C}$ 's merupakan faktor penting dalam setiap keputusan atas permohonan kredit, jadi setiap permohonan kredit harus melalui tahap penilaian kredit yang berupa analisis 5 C's.Namun mengingat kondisi ekonomi 
dan moneter menimbulkan dilema bagi Bank. Disatu pihak terdapat desakan yang makin mengeras untuk menyalurkan dana Bank kepada masyarakat, dilain pihak tanpa desakan apapun Bank memang harus menempatkan dananya dalam aktiva yang menghasilkan bunga, jika tidak Bank akan mengalami kerugian karena tetap harus membayar biaya bunga kepada para nasabah penyimpan dana. Penempatan dalam aktiva yang menghasilkan (earning assets) sebenarnya banyak macamnya akan tetapi bankir tetap mengalami tekanan untuk menyalurkan dalam bentuk fasilitas kredit kepada para debitur.

$$
\text { Dilema yang memaksa }
$$

manajemen Bank memberikan fasilitas kredit secara tidak konsisten dengan kebijakan dan prosedur yang telah ditetapkan oleh Bank Indonesia adalah (Gunarto Subardi 2006) :

1. Independensi Manajemen Bank.

Sebagai profesional Manager Bank seharusnya dapat memutuskan kebijaksanaan perkreditan secara independen sesuai dengan intuisi bisnisnya. Namun kenyataannya dilapangan para Manager Bank harus memperhatikan kehendak

pemilik atau pemegang saham mayoritas baik itu Bank Swasta atau pejabat pemerintah sebagai representasi dari negara bagi bank milik negara (BUMN). Bukan saja harus memperhatikan kehendak yang dinyatakan dalam Rapat Umum Pemegang Saham akan tetapi juga kehendak atau policy yang ditetapkan secara privat.

2. Persaingan Yang Ketat.

Sejak deregulasi ekonomi tahun 1988 jumlah Bank umum di Indonesia bertambah dengan menjadi lebih dari 300 Bank. Belum termasuk Bank Asing yang sejak tahun 1970 makin kokoh memainkan peranannya diberbagai kota. Ini mengakibatkan persaingan antar Bank yang amat ketat sehingga nasabah yang baik (prime customers) lebih sulit dicari oleh Bank. Posisi tawar Bank menjadi melemah sehingga terpaksa memberikan kemudahan bagi calon debitur. Sering pula syarat-syarat administrasi bahkan yang bersifat yuridis terpaksa dikesampingkan atau ditunda dan debitur diperkenankan untuk menarik dana kredit walaupun syarat administratif belum selesai.

3. Kredit Program

Kredit program pada umumnya massal dan bersifat politis, seringkali memberikan beban lebih berat kepada Bank khususnya Bank BUMN. Dalam kondisi demikian mana mungkin Bank mengadakan analisis perdebitur disamping terlalu banyak jumlahnya juga mereka tidak paham tentang pencatatan keuangan sehingga datadata untuk analisa sukar didapat. Bila terhadap mereka diterapkan

standar analisa maka secara tehnis banyak yang tidak memenuhi syarat memperoleh kredit.

4. Loyalitas Nasabah.

Loyalitas atau kesetiaan nasabah menjadi lebih penting lagi bila dikaitkan dengan biaya. Biaya untuk mempertahankan nasabah yang loyal lebih murah mengatasi hal ini adalah dengan memahami ekspektasi nasabah. Sekalipun ekspektasi nasabah sulit untuk dipenuhi namun pemahaman ini akan mempermudah Bank dalam usaha menciptakan sekaligus mempertahankan nasabah yang loyal.

\section{Mengatasi Kredit Bermasalah}

Hambatan-hambatan diatasi dengan dua cara, yang pertama dilakukan sebelum pengikatan yaitu:
a. Tujuan kreditnya jelas;
b. Analisa yang tepat;
c. Trade ceking;
d. Tidak over finance;
e. Legalitas usaha dan subyek hukum benar;
f. Jaminan cover;

Upaya langkah kongkrit bank untuk menyelamatkan kredit agar kredit yang diberikan lancar kembali tergolong dalam kredit tidak lancar, diragukan, kredit macet untuk kembali menjadi kredit lancar sehingga debitur mempunyai kemampuan kembali membayar pada bank.

Menurut Surat Edaran Bank Indonesia Nomor 23/12/BPPP tanggal 28 Februari 1991, upaya-upaya 
penyelamatan kredit yang dapat dilakukan oleh bank selama kredit berjalan adalah sebagai berikut:

a. Penjadwalan Kembali (Rescheduling), yaitu dengan melakukan perubahan syarat-syarat perjanjian kredit yang berhubungan dengan jadwal pembayaran kembali kredit atau jangka waktu kredit, termasuk grade period atau masa tenggang, baik termasuk perubahan besarnya jumlah angsuran

b. Persyaratan kembali (Reconditionong), dengan melakukan perubahan atassebagian atau seluruh syaratsyarat perjanian kredit, yang tidak hanya

terbatas pada perubahan jadwal angsuran dan atau janka waktu kredit saja. Namun perubahan tersebut tanpa memberikan tambahan kredit atau melakukan konversi atas seluruh atau sebagian dari kredit menjadi perusahaan.

c. Penataan Kembali (Restructuring) yaitu suatu upaya dari bank yang berupa melakukan perubahanperubahan syarat-syarat perjanjian kredit yang berupa pemberian tambahan kredit, atau melakukan konversi atas seluruh atau sebagian dari kredit menjadi equity perusahaan, yang dilakukan dengan atau tanpa Rescheduling dan atas Reconditioning.

\section{Kesimpulan Dan Rekomendasi}

1.

acuan yang utama untuk menilai

kelayakan pemberian kredit yang

berupa:

a. Dari segi Character (watak), maka penilaiannya meliputi Riwayat hidup calon debitur, mencakup reputasi calon debitur di lingkungan bisnis/usahanya dan riwayat hubungan calon debitur dengan Bank, dimana disini hubungan dengan PT. Bank Pembangunan Daerah Jawa Timur atau hubungan dengan Bank lain.

b. Dari segi Capacity (kemampuan), penilaiannya meliputi pengalaman dari calon Debitur dalam mengelola usahanya, termasuk sumber daya manusia yang dimilikinya.

c. Dari segi Capital (modal), penilaiannya keuangan perusahaan yang dilihat dari laporan keuangan yaitu Neraca dan Laporan Rugi dan Laba 3 tahun terakhir.

d. Dari segi Collateral (jaminan), penilaian meliputi barang jaminan yang diserahkan calon debitur kepada Bank sebagai jaminan atas kredit yang diterimanya.

e. Condition Of Economy (keadaan ekonomi), menilai keadaan usaha dari calon debitur, serta keadaan pasar dan kebijakan pemerintah pada saat kredit berlangsung.

Faktor yang ada dalam Analisis 5 C's merupakan faktor-faktor penting dalam menjamin mutu kredit. Setiap permohonan kredit yang telah melewati tahap penilaian kredit (analisis 5'C), maka kredit yang berjalan akan menjadi kredit yang faktor risikonya minim. Hal ini dapat berarti bahwa Analisis 5'C yang baik membantu dalam menghasilkan kredit dengan mutu yang baik dengan faktor risikonya yang rendah.

Sebelum diputuskannya permohonan kredit diterima atau tidak, maka setelah penilaian kelayakan kredit, kemudian melalui tahap Wawancara pertama, peninjauan ke lokasi, hingga wawancara kedua. Setelah itu baru diputuskan permohonan kredit tersebut diterima atau tidak.

2. Cara mengatasi hambatan-hambatan, dilakukan dengan dua cara:

2.1. Sebelum kredit diputuskan diterima/tidak :

a. Tujuan kreditnya jelas;

b. Analisa yang tepat;

c. Trade ceking (konfirmasi dengan pihak ketiga);

d. Tidak over finance;

e. Legalitas usaha dan subyek hukum benar;

f. Jaminan diberikan $120 \%$ dari kredit; 
2.2. Setelah kredit berjalan (belum jatuh tempo) :
a. Penjadwalan kembali (Rescheduling);
b. Persyaratan kembali
(Reconditioning);
c. Penataan Kembali (Restructuring).

\section{E. Daftar Pustaka}

